\title{
Is there any Fisherian Link between Nominal Interest Rate and Inflation in Albania?
}

\section{Güngör Turan}

\author{
Ph.D, Department of Economics, Epoka University, Tirana, Albania,
}

gturan@epoka.edu.al

\section{Vjollca Curri}

\author{
Master Student at Banking and Finance Department, Epoka University, Tirana, Albania,
} v.curri@hotmail.com

\section{Doi:10.5901/mjss.2014.v5n13p334}

\begin{abstract}
The aim of this paper is to examine the implementation of the well-known Fisher Hypothesis (FH) for Albania. Fisher Hypothesis investigates the relationship that exists between the expected inflation and interest rates and to which extent holds the Fisher effect, for the period 1997-2013. The first step of the study is an introduction of the Fisher Hypothesis, its definition and the main points. The second part includes an econometric model, by using the Johansen Cointegration Test for the Albanian quarterly nominal interest rate and quarterly inflation rate, in order to explain as correctly as possible the relationship between inflation and interest rate. In the end the empirical results disclosed that there is a long run relationship between nominal interest rates and inflation. This indicates that full Fisher hypothesis does not hold but there is a very strong Fisher effect in the Case of Albania regarding the period under study.
\end{abstract}

Keywords: Fisher Hypothesis, Interest Rate, Expected inflation

\section{Introduction}

The Fisher hypothesis has been much discussed topic. During years the hypothesis is used as a theoretical framework because it has serious subaudition in rising up the monetary policy in a country. More precisely,interest rates play an substancial role in fighting one of the major problems of a state's economy: inflation.

Inflation adverts to raise the price level in general. High inflation raises the problem of developing and developed economies. So high inflation rates have always been not likely for any economy because it will reduce the aggregate demand, increase unemployment, decrease output, and very hard for the balance. While having high inflation and high interest rates prevent economic growth by discouraging investment and decrease productivity. Nominal interest rate is holder as an instrument for achieving the inflation target. Interest rate is one of the most significant tools that government uses properly to control the inflation. It affect directly in the consumer's behaviour. The relationship between the interest rates and the future inflation has been studied in many countries and over diverse periods. Fisher Effect has been found really strong in various countries, example of United States, Canada and UK (1979).

The Fisher effect, also called Fisher Hypothesis is determined as: the one-for-one relation between the expected inflation rate and the nominal interest rate. Irving Fisher estimates the relationship between the inflation and for both real and nominal interest rates. The Fisher effect declared that the real interest rate equals the nominal interest rate minus the expected inflation rate. Ergo, the real interest rates fall as the inflation increases, but for nominal rates increase at the same rate as the inflation. The so-and-so Fisher equation which is:

$$
r=R-\pi^{e}
$$

The Fisher equation is an identity which regards the nominal interest rate (i), the real interest rate(r), and the (expected) inflation rate $\boldsymbol{\pi}$ e and $\boldsymbol{\pi}$, relatively. It can be exhausted in ex ante and ex post analysis. So there are two different versions, hanging on the Information available for the inflation rate:

The ex-ante Fisher equation adapt the costs of borrowing, the nominal interest rate for the effects of expected inflation (the expected inflation rate, expressed with $\pi \mathrm{e}$ )

The ex- post Fisher equation break down the nominal interest rate into the real interest rate and the actual realized inflation rate, $\pi$

Fisher hypothesis lay down real interest rate as the difference between nominal interest rate and expected inflation rate. In order to hold Fisher Hypothesis in a strong form, nominal interest rate proceeds one-to-one with expected inflation rate. Whether the nominal interest rate and inflation rate are either integrated of order one and the two variables should 
be cointegrated with the slope coefficient of unit value that the real interest rate is covariance stationary.

As recognized, cointegration concept is connected with long run equilibrium relationship between two or more variables. This empirical relationship has significant subaudition for the macroeconomic policy because, whether the hypothesis holds in the long run, the monetary policy does not affect the real interest rate, leaving the ex-ante real interest rate unaltered. This would mean that real interest rates are not connected to the expected inflation and are situated by the real factors in an economy, like the time preference and the capital productivity (et al Payne and Ewing, 1997; et al Million, 2004).

This paper examines the availability of Fisher hypothesis in Albania for the period 1997Q1-2013Q3.For this purpose, we employ Johansen cointegration test for changes on the relation between Albanian quarterly nominal interest rate and quarterly inflation rate. This method would give us more reliable results.

In this paper, there will be presented the case of Albania which is a state located in the South Eastern Europe and commanded by a transition economy.The unstable economic history that Albania has, after the Communist regime that left it steps behind the developed countries and eventually the absence of organization in the economic institutions. Apart from the fact that BoA isnt a strong financial institution as the developed countries central banks are, it continusly tries to give sense to the economic situations offered in the Albanian reality.

The main objective of this paper is to find out the relation between nominal interest rate and inflation in Albania in the long run.In the first part of the paper, there will be presented a general idea about the concept of Fisher Hypothesis .Through this overall description, the paper's basic idea gets a simple understanding. The second part of the paper is dedicated to the literature review related to the fisher effect, what others have found concering with the relation of interest rate and inflation in their countries and what methodology they used in their researches. The third part instead is dedicated Data and Methodology part by expounding the period of time that is used in the study, what method is used in order to discover the relationship between interest and inflation in long run, the regression model and its determinants. The fourth and the final part include the practical section of the paper. In this section it will be included the econometric equation containing the dependent variable (nominal interst rate) and the other independent variables (inflation rate). This part shows the results of the ADF test in order to be sure of having stationary time series. Then is performed the Johansen Cointegration Test to find out if exists a long term relationship between interest and inflation in Albania. Eventually part of the study includes the Conclusions and Implication out coming from this paper.

\section{Literature Review}

The hypothesis, proposed by Irving Fisher et al(1930) that the nominal rate of interest should reflect movements in the expected inflation rate has been the subject of much empirical researches in many developed countries. This asset of literature can be attributed to different factors including the main role that the nominal rate of interest and the most important, the interest real rate plays in the economy. Rate of interest real is a significant determinant of investment and saving of households and businesses, and ergo decisive in the development and growth of an economy (Duetsche Bundesbank,et al 2001).

Mundell et al (1963) and Tobin et al(1965) argue that nominal interest rates should adapt by less than one-for-one owing to the impact of inflation on wealth and the subsequently savings.

Sargent et al (1969), across a technique named geometrically-declining dissolved model of past price changes, adverted to bond market's loanable funds model. This was pursued by Gibson et al(1970), and both replicated Fisher's views, especially with regard to the method in which expectations are created. Gibson et al (1972) finally reduced such time lag to six months, wherefore emphasizing the view that expectations are created more quickly and influence interest rates greatly.

Darby et al (1975) and Feldstein et al (1976) highlight that the effects of tax would outcome in a more than one-forone arrangement to expected inflation,whereas Shome, Smith and Pinkerton et al(1988) indicate a premium needs to be incorporated in nominal interest rates to calculation for covariance risk.

Fama et al (1976) in the analysis of U.S Treasury Bills(1953-1971) found that the nominal interest rates in market include all information about future inflation rates in time series of the past inflation rates. The findings of Fama seem to hint that, through the period under revision, the real interest rates were constant. Gibson et al (1972),by the use of Livingston survey,a model composing expectations of economists, as an alternative calculation of inflation expectations. This can prove to move along the range of the market, especially if their personal interests are at risk.Fama et al (1976) and Makin and Tanzi et al(1984), who postulated that the further high interest rates in the USA at that time could be explained by the positively probability distribution of inflation prediction. 
Mishkin et at(1992) point out that the Fisher hypothesis held only during periods where inflation and interest rates manifest stochastic trends. He was one of the first to behavior a unit root test on both nominal interest rates as well as inflation.

Mishkin told that the standard Fisher equation is submited to the phoney regression phenomenon as it is explained by Granger and Newbold et al(1974) and Phillips et al (1986).

Wallace and Warner et al (1993) followed up this study by carrying out cointegration tests for inflation and interest rates. They were both found to have an I(1) process. A series of authors, through their time series analyses, tested positive for cointegration. These include MacDonald and Murphy (1989), Kao and Chiang (2000), Atkins and Coe (2002), amongst others.

Fisher effect also has significant implications for monetary policy which need to be considered by central banks. A substantial amount of research has been conducted in developed countries and emerging economies to test, prove and establish this hypothesis: between the most recent papers are those by Garcia et al (1993), Mishkin and Simon et al (1995), Crowder and Hoffman et al (1996),Choudhry et al(1997), Koustas and Serletis et al(1999), Muscatelli \& Spinelli et al(2000)Carneiro, Divino and Rocha et al (2002), Atkins \& Serletiset al(2002), Miyagawa \&Moritai et al(2003), Ghazali \& Ramlee et al(2003), Esteve, Bajo-Rubio and Diaz-Roldan et al(2003), Jorgensen and Terra et al(2003),Fahmy \& Kandil et al(2003).

Peng et al (1995) uses the Johansen cointegration analysis on three-month interest rates and CPI inflation to confirm the Fisher effect for the UK,US and France. His empirical analysis offers strong proof in favor of the Fisher relationship in the US, UK and France, whereas the inflation coefficients received for Germany and Japan are smaller than one.

Lungu (1998) agreed with Rose that an evaluation of whether nominal rates and expected inflation are cointegrated is tantamount to testing the stationarity of the real rate of interest. He did not find cointegration for the U.S. between 1972 and 1980, and attributed government macroeconomic policies as key to this outcome. Economic data is deemed distorted and agents' formation of inflation expectations is affected. He also reaffirmed Mishkin's view that the two oil shocks arising during the period under examination further exacerbated such distortions.

Krugman and Obstfeld et al (2003) design the Fisher effect saying that all things will be equal, a country rise in expected inflation rate will definitively cause an equal rise in interest rate, that the deposits of its currency bid a similarly fall in the expected inflation rate also will eventually cause a fall in the interest rate.

Gul and Ekinci (2006) found a long run relationship between nominal rate of interest and inflation by applying Johansen cointegration technique in Turkey; along found unidirectional relationship which flits from the interest rate to the inflation rate.

Obi et al (2009) examined the authenticity of fisher effect in Nigeria by using the cointegration and error correction technique. They receded money supply, inflation rate and found fractional fisher effect in Nigeria. They proposed that the government should invest in productive activities to increase money supply and curb inflation.

\section{Data and Methodology}

In order to examine the relation between nominal interest rate and inflation rate in Albania needs not only the theoretical concepts, but also need a practical and econometric study as well. This study employs quarterly data from 1997 to 2013 so for a 17 year period. The data for this research are obtained from Central Bank of Albania (BoA).

The regression model in this study is:

$I N T=\alpha+\beta_{1} I N F+e$

Where: $\alpha$ : is the intercept

$\beta_{1}$ Is the estimated regression coefficients

e: is the error term

GDP: Gross Domestic Product is the dependent variable

INF: Inflation rate is the independent variable

The hypothesis for this equation is represented by the following:

$\mathrm{HO}$ : Nominal interest rate has a significant impact on the inflation rates in the long run

$\mathrm{H} 1$ : $\mathrm{HO}$ is not true

In Figure 1 is shown the line graph where it is noticed that the variables approximately goes on together, but from time to time there are some fluctuations. In Figure 2 is shown a graphical scatter plot that shows the relationship is not phoney so it can be understood that occasional relation exists between inflation and interest. 


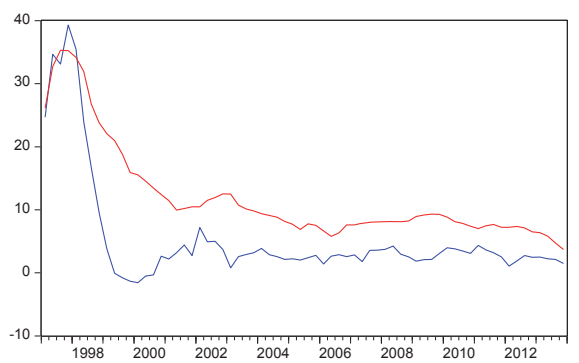

Figure 1: Line graph representing Inflation and Nominal interest rate

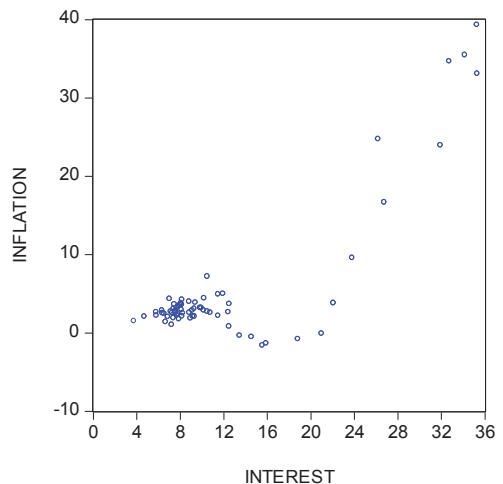

Figure 2: Scatter plot representing Inflation and Interest

In the first stage of the study is executed the Augmented Dickey-Fuller (ADF) test at $5 \%$ level of significance in order to secure that the series used in the model are stationary time series diversely the results might not hold much significance.

Further, in order to define if exists a long run relationship among the inflation and the interest rate the Johansen Cointegration Test is performed. So that to have a relationship between the variables the Trace Statistic must be greater than $50 \%$ critical value. Also the maximum eigenvalue test must be greater than $50 \%$ critical value.

\section{Empirical Findings}

In Figure $1(a, b)$ (see appendix) and as well in table 1 are shown the group statistics performed in order to test the distribution of data. After checking the Skewness and Kurtosis for the variables, due to the presence of unit root on the variables the results showed to be asymmetric and not in a bell shaped. In all the three variables data neither the Skewness was close to one nor was the Kurtosis near to 5.

Table 1. Group Statistics

\begin{tabular}{|l|c|c|}
\hline & INTEREST & INFLATION \\
\hline Mean & 11.98078 & 5.462557 \\
\hline Median & 8.890000 & 2.798217 \\
\hline Maximum & 35.30667 & 39.32504 \\
\hline Minimum & 3.750000 & -1.576482 \\
\hline Std. Dev. & 7.813402 & 8.778207 \\
\hline Skewness & 1.853169 & 2.759324 \\
\hline Kurtosis & 5.393654 & 9.497927 \\
\hline Jarque-Bera & 55.15516 & 205.9225 \\
\hline Probability & 0.000000 & 0.000000 \\
\hline Sum & 814.6933 & 371.4539 \\
\hline Sum Sq. Dev. & 4090.300 & 5162.814 \\
\hline Observations & 68 & 68 \\
\hline \multicolumn{2}{|c|}{} \\
\end{tabular}


Figure 3 (a) Interest

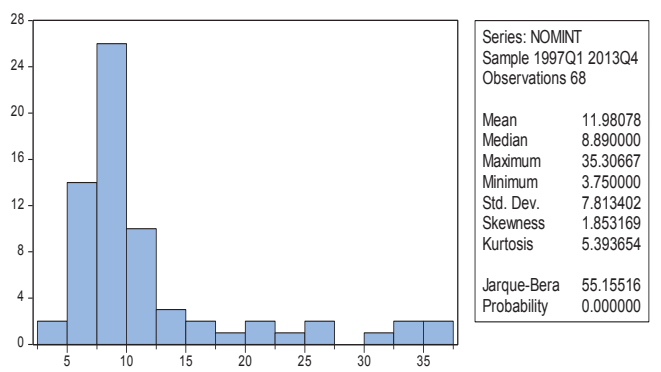

Figure 3 (b) Inflation
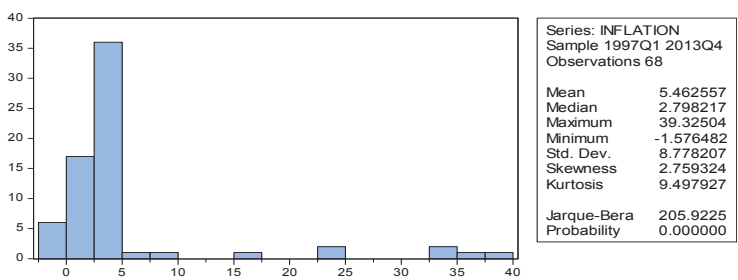

So to examine whether the series were stationary time series Augmented Dickey-Fuller (ADF) test was performed. Since the calculated ADF t-statistic $(-1,949)$ is greater than the $5 \%$ critical value of $(-3,496)$ do not reject the null of nonstationary (NOMINT has a unit root).First result showed that for nominal interest rate has a unit root" was not rejected as at $5 \%$ critical values since the calculated t-statistics for nominal interest rate was greater than the $5 \%$ of critical value. So according to these results the presence of unit roots in the underlying series points toward the non-stationary of the underlying series. So if the depended and independent both show presence of unit roots, the regression result doesn't hold much meaning.

Null Hypothesis: NOMINT has a unit root

Exogenous: Constant, Linear Trend

Lag Length: 14 (Fixed)

\begin{tabular}{llll}
\hline \hline & & t-Statistic & Prob. $^{\star}$ \\
\hline \hline Augmented Dickey-Fuller test statistic & & -1.949222 & 0.6148 \\
\hline Test critical values: & 1\% level & -4.140858 & \\
& 5\% level & -3.496960 & \\
& $10 \%$ level & -3.177579 & \\
& & & \\
& & &
\end{tabular}

*MacKinnon (1996) one-sided p-values.

Null Hypothesis: INFLATION has a unit root

Exogenous: Constant, Linear Trend

Lag Length: 14 (Fixed)

\begin{tabular}{lccc}
\hline \hline & & t-Statistic & Prob. $^{*}$ \\
\hline \hline & & & \\
Augmented Dickey-Fuller test statistic & & -2.161181 & 0.5007 \\
\hline Test critical values: & 1\% level & -4.140858 & \\
& 5\% level & -3.496960 & \\
& $10 \%$ level & -3.177579 & \\
& & & \\
\hline \hline
\end{tabular}

*MacKinnon (1996) one-sided p-values.

Figure 2. ADF tests for inflation and interest

This is the reason that in order to have the necessary stationary time series and to reject the hypothesis that variables 
have a unit root, we are having another Augmented Dickey-Fuller Unit Root test by performing the first difference on the variables needed so that the regression to be significant.

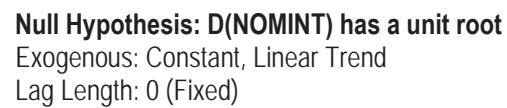

\begin{tabular}{llcc}
\hline \hline & & t-Statistic & Prob.* $^{*}$ \\
\hline \hline Augmented Dickey-Fuller test statistic & & -7.117164 & 0.0000 \\
\hline Test critical values: & $1 \%$ level & -4.103198 & \\
& $5 \%$ level & -3.479367 & \\
& $10 \%$ level & -3.167404 & \\
& & & \\
\hline \hline
\end{tabular}

*MacKinnon (1996) one-sided p-values.

Null Hypothesis: D(INFLATION) has a unit root

Exogenous: Constant, Linear Trend

Lag Length: 0 (Fixed)

\begin{tabular}{cccc}
\hline \hline & & t-Statistic & Prob.* \\
\hline \hline Augmented Dickey-Fuller test statistic & & -6.957445 & 0.0000 \\
\hline Test critical values: & $1 \%$ level & -4.103198 & \\
& $5 \%$ level & -3.479367 & \\
& $10 \%$ level & -3.167404 & \\
& & & \\
\hline \hline
\end{tabular}

*MacKinnon (1996) one-sided p-values.

Table 3. ADF test after taking the first difference

Finally, after performing the First Difference of the Augmented Dickey-Fuller Unit Root Test and eventually having stationary time series is the application of Johansen Cointegration test in order to study if there is a long term relationship between the variables. In accordance with test results it is indicated that there exists a Cointegration relation between variables providing that Trace Statistics (70.593) is greater than 5\% Critical Value (15.494). Moreover by looking at the Maximum Eigenvalue test the max eigenvalue statistic (60.216) is greater than 5\% Critical Value (14.264).

\section{Unrestricted Cointegration Rank Test (Trace)}

\begin{tabular}{|c|c|c|c|c|}
\hline $\begin{array}{l}\text { Hypothesized } \\
\text { No. of CE(s) }\end{array}$ & Eigenvalue & $\begin{array}{l}\text { Trace } \\
\text { Statistic }\end{array}$ & $\begin{array}{c}0.05 \\
\text { Critical Value }\end{array}$ & Prob.** \\
\hline None * & 0.615505 & 70.59354 & $>15.49471$ & 0.0000 \\
\hline At most 1 * & 0.151859 & 10.37665 & 3.841466 & 0.0013 \\
\hline
\end{tabular}

Trace test indicates 2 cointegrating eqn(s) at the 0.05 level

* denotes rejection of the hypothesis at the 0.05 level

**MacKinnon-Haug-Michelis (1999) p-values 
Unrestricted Cointegration Rank Test (Maximum Eigenvalue)

\begin{tabular}{lccc}
\hline \hline $\begin{array}{l}\text { Hypothesized } \\
\text { No. of CE(s) }\end{array}$ & Eigenvalue & $\begin{array}{c}\text { Max-Eigen } \\
\text { Statistic }\end{array}$ & $\begin{array}{c}0.05 \\
\text { Critical Value }\end{array}$ \\
\hline \hline None * & 0.615505 & 60.21689 & $>14.26460$ \\
At most 1 & 0.151859 & 10.37665 & 3.841466 \\
\hline \hline
\end{tabular}

Max-eigenvalue test indicates 2 cointegrating eqn(s) at the 0.05 level

* denotes rejection of the hypothesis at the 0.05 level

**MacKinnon-Haug-Michelis (1999) p-values

Table 4. Johanson Cointegration Test

In other words a long run stable relationship exists between nominal interest rate and inflation rate and they move together in the long run. Thus occasional relation exists between inflation and interest rate. The increases of interest extend inflation in Albania.

\section{Conclusion and Implications}

In this paper is tested the relationship the cointegrating relationship between nominal interest rates and expected inflation in the Albanian economy. The results of the unit root tests indicated the variables under study were processes.

The direction is from inflation, which is the independent variable, to the interest rates, being the dependent variable. The cointegration results show that there is long run relationship between the nominal interest rates and the expected inflation, which insinuate that nominal interest rates and expected inflation move together in the long run.

The Albanian case supports the Fisher effect theory. At this paper, Albanian economy in a seventeen year period (1997-2013) has been studied. Findings show witness proving the Fisher effect in those years as inflation causes at some extent the interest rates to move in the same direction. However, there isn't seen one-to-one relationship as the theory stated.

\section{References}

Akinlo, A. Enisan, 2011. A re-examination of the Fisher Hypothesis for Nigeria. Akungba Journal of Economic Thought. Vol.5, Number 1 Anoruo, E. (2002).Stability of the Nigerian M2 Money Demand Function in the SAP Period. Economics Bulletin 14: 1-9.

Atkins, F.J. and Serletis, A., 2002. A bounds test of the Gibson paradox and the Fisher effect: evidence from low-frequency international data. Discussion Paper 2002-13. Calgary: Department of Economics, University of Calgary.

Booth, G. G., Ciner, C., 2001. The relationship between nominal interest and inflation: international evidence. Journal of Multinational Financial Management 11, 269-280.

Bullard, J.B. 1999. Testing long-run monetary neutrality propositions: Lessons from the recent research. Federal Reserve Bank of St. Louis Review 81, 57-77.

Carneiro, F.G., Divino, J.A.C.A. and Rocha, C.H., 2002. Revisiting the Fisher hypothesis for the cases Argentina, Brazil and Mexico. Applied Economics Letters. 9, 95-98.

Cheung, Y., Lai, K., 1993. Finite-sample sizes of Johansen"s likelihood ratio tests for cointegration. Oxford bulletin of Economics and Statistics 55, 313-328.

Choudhry, A., 1997. Cointegration analysis of the inverted Fisher effect:Evidence from Belgium, France and Germany. Applied Economics Letters 4, 257-260.

Crowder, W.J. and Hoffman, D.L., 1996. The Long-run relationship between nominal interest rates and inflation: The Fisher equation revisited. Journal of Money, Credit, and Banking. 28, 1:102-118.

Darby,M.R.,(1975),"The financial and tax effects of monetary policy on interest rates", Economic Inquiry, 13, 266-276

Deutsch Bundesbank report 2001. "Real Interest Rates: Movement and Determinants," pp. 31 47, July.

Dutt, S.D. and Ghosh, D., 1995. The Fisher hypothesis: Examining the Canadian experience. Applied Economics. 27, 11:1025-1030.

Esteve, V., Bajo-Rubio, O. and Diaz-Roldan, C., 2003. Testing the Fisher effect in the presence of structural change: a case study of the UK, 1961-2001. Documento de trabajo, Serie Economia E2003/22. Sevilla: Fundacion Centro de Estudios Andaluces.

Fama, E.F., 1976. Inflation uncertainty and expected returns on treasury bills. Journal of political economy, 84, 427-448.

Gul, E. and A. Ekinci, 2006. The Causal Relationship between Nominal interest rates and Inflation: The case of Turkey. Scientific Journal of Administrative Development, (4): 54-69. 
Mankiw, G. (2006) Macroeconomics 6th edition, New York: Worth Publishers

Mishkin Frederic S., The Economics of Money, Banking, and Financial Markets,7th ed., Columbia University, 2004.

Mundell, R.,(1963),"Inflation and real interest", The journal of Political Economy, 71 ,280-283.

Obi, B., A. Nurudeen and O.G. Wafure, 2009.An Empirical investigation of the Fisher Effect in Nigeria: Co-Integration and Error Correction Approach., International Review of Business Research Papers, 5(5): 96-109.

Peng, W., 1995. The Fisher hypothesis and inflation persistence. Evidence from five major industrial countries. IMF working paper, no. 95/118. 